\title{
Accounting
}

\section{Profitability of energy sector companies of Saudi Arabia: Mutual analysis based on revenue and investment}

\author{
Anis Ali ${ }^{*}$ and Mohammad Zulfeequar Alam ${ }^{\text {b }}$
}

${ }^{a}$ Department of Management, College of Business Administration, Prince Sattam Bin Abdulaziz University, Al kharj-11942, Saudi Arabia

${ }^{b}$ Department of Marketing, College of Business Administration, University of Business and Technology, Jeddah-21361, Saudi Arabia

\section{H R O N I C L E}

\begin{tabular}{l}
\hline Article history: \\
Received: October 30, 2020 \\
Received in revised format: \\
November 302020 \\
Accepted: December 30, 2020 \\
Available online: \\
December 30,2020 \\
\hline Keywords: \\
Profitability \\
Energy companies \\
Saudi Arabia \\
Rank correlation \\
Total resources \\
Owners' equity
\end{tabular}

\section{Introduction}

The profitability of the business organization is the relative measurement and reveals the profit earning capacity of the business organization. The absolute profit contained in the income and expenditure statement reveals the results of the business activities for a particular period. The absolute amount of the profit indicates only outcomes of the operational activities for the specific period while unable to explain the efficiency of the business organization in terms of profit-earning capacity. There is a difference between the absolute profit and profitability or profit-earning capacity of the business organization. Sometimes, it is observed that the business organization earning massive absolute profit with lower profitability while other business organizations earn low absolute profit with high profit earning capacity. The profit earning capacity of the business organization depends on internal and external factors of the business environment. The internal factors are controllable and indicate the managerial efficiency of the business organization specifically lowering the manufacturing and administrative expenses. Lowering the manufacturing expenses can be minimized through utilizing the advanced technology of production, production at a high level, and skilled and low-cost labor. Low manufacturing inputs enhance the absolute gross profit and gross profitability of the business organization. The absolute net profit and net profitability are backed by the absolute gross profit and gross profitability and influenced by the administrative expenses of the business organization. The managerial efficiency, and low office and administrative expenses

* Corresponding author.

E-mail address: ah.ali@psau.edu.sa (A. Ali)

(C) 2021 by the authors; licensee Growing Science, Canada doi: 10.5267/j.ac.2020.12.019

\begin{abstract}
The profitability of the business organization is the relative measurement and explores the profit earning capacity. There are two concepts of measuring profitability, which are profitability based on
revenue, and investments. Gross and net profitability are the means of expression of the profitability based on revenue while investment profitability can be measured based on owners' investment and total investment or total assets. Secondary data from the websites of the energy sector companies are taken for the study and ratio analysis, rank correlation is applied to get the similarity or differences in
the profitability and relational relationship of the energy sector companies of Saudi Arabia. The study reveals that there was a significant difference in the profitability of the energy sector companies. Possibly, internal and external factors of the business organizations govern the profitability. There is a perfect and positive relational correlation between revenue and profitability while a highly negative underutilization of the resources. Enhancement of velocity of operational activity is necessary to enhance the operational level of energy sector companies of Saudi Arabia. There is a need to control the indirect manufacturing and administrative expenses in smaller organizations and further investment in the energy sector companies is not advisable.
\end{abstract}

(C) 2021 by the authors; licensee Growing Science, Canada 
enhance the net profit and net profitability of the business organization. Indirect manufacturing and administrative expenses play a vital role on the absolute profit and profitability. As the level of production or activities increases, indirect manufacturing and administrative expenses decrease proportionately to the level of activities or turnover. The external factors also affect the absolute profit and profitability. The price and demand for the products and services are the external factors that affect the profit and profitability of the business organization, ultimately. The profitability is based on the turnover that measures the manufacturing and administrative efficiency in the context of turnover while the turnover is the reflection of the velocity of the utilization of the resources. So, logically, the profitability of a business organization can also be measured in the context of resources or funds invested in the business organization. There are two views to measure the profitability based on the investments or resources i.e. profitability for real owners/ shareholders point of view, and profitability on resources or funds invested. The profitability of funds invested or total resources indicates the level of efficiency of utilization of resources or velocity of utilization of resources while the profitability of owners' funds reveals the level of return on the funds invested by the owners. The profitability of the resources or funds invested is governed by the velocity of activities and profit margin, i.e., difference between revenue and expenses. Profitability on owners' funds is additionally governed by the debt-equity ratio. In the case of prosperity, the high debt-equity ratio is favorable while the low debt-equity ratio is suitable in case of recession. The energy sector is very prominent in Saudi Arabia and plays a vital role in the economy. Saudi Arabia possesses $17 \%$ of the world's oil and gas reserves and contributes $50 \%$ to the gross domestic product (GDP) of Saudi Arabia. The oil prices in Saudi Arabia starts to decline from 2014 and affected the profitability of energy sector companies (Ali, 2020d). There is no specific study available to explore the differences among profitability and the relationship between revenue and profitability and revenue and resources or funds invested. The present study focuses on the similarity among the profitability of the leading energy sector companies and also defines the relationship between the profitability, and revenue, resources of the leading energy sector companies of Saudi Arabia.

\section{Literature Review}

Al-Shuaibi et al. (2016) explored that competitiveness and innovation improve the financial performance of the business organization. Ali and Abu Theeb (2018) indicated that the cost of products was the sole factor that leads to the negative financial performance of petrochemical in Saudi Arabia. Akhtar and Asif (2017) observed that the efficiencies and optimum utilization is the resources enhance the financial performance and suggested production at a larger scale and utilization of the resources to attain the expected growth. Samargandi et al. (2014) indicated that the financial performance of the petrochemicals companies is not based on the financial development while some other external and internal factors are responsible for the financial performance of the firm. Khan \& Khokhar (2014) focused on the operational performance and advocated that operational velocity governs the profitability of the petrochemical companies of Saudi Arabia. Alagathurai (2013) and Aminu (2012) found a significant and positive relationship between profitability and liquidity of Sri Lankan trading companies while Sinha et al. (2016) found positivity between the profitability and cash management. Kumar et al. (2016) revealed that the effective management of current assets and liabilities affect profitability. Priya and Nimalathasan (2013) advocated the optimum balance between profitability and liquidity based on the negative relationship thereof. Sodha (2020) found in his study that profitability and liquidity mutually exclusive events. Pushparaj and Pimplapure (2019) found the positivity between the short-term or long-term liquidity and profitability in pharmaceutical companies of India. Farhan et al. (2019) explored that corporate governance governs the liquidity and profitability of the pharmaceutical of India. Ehiedu (2014) observed a positive relationship between liquidity and profitability and suggested a balance between liquidity and profitability to run the uninterrupted business activities. Ben-Caleb et al. (2013) suggested that the extreme polar liquidity is not favorable for the smooth running of the business activities and profitability. Panigrahi et al. (2018) studied the negativity between the profitability and liquidity and found the uninterrupted business activities in pharmaceutical companies of India. Further, Panigrahi (2019) explored that the liquidity and profitability relationship vary from company to company. Bhunia and MuKhuti (2011) explained that working capital management is an important means to balance between liquidity and profitability. Rehman, et al. (2015) considered 99 companies listed in the Saudi stock exchange (TADAWUL). The Return on Assets (ROA) and Return on Equity (ROE) are calculated to know the profitability while liquidity is measured by the current ratio, liquidity ratio, and absolute ratio. They found that that there is a negative and insignificant relationship between profitability and liquidity of the Saudi companies listed on the Saudi stock exchange. Lele (2016) studied the growth, operational profitability, and return on owners' fund and found the negativity in revenue growth rate by $141.5 \%$, net operational profitability by $15.1 \%$, and $25.2 \%$ by return on owners' fund during the period 2013 to 2015 in non-financial sector companies registered in Saudi Arabia. Above all studies explain the relationship between profitability and liquidity and suggested maintaining an optimum level of liquidity for the smooth operation of business activities. However, there is no specific study available to explain the similarity in profitability in the context of revenue or turnover and investment of energy sector companies of Saudi Arabia. Present study focuses on the similarity and relational study of revenue and profitability, and equity and return on equity, assets and return on assets to know that the operational profitability and profitability on investment is governed by the level of activities or revenue or funds invested in the business organization. 


\section{Research Hypotheses}

To analyze the profitability based on revenue and investment, hypotheses can be divided into two categories:

$\mathrm{H}_{01}$ : There is no significant difference among the operational profitability, return on investment of energy sector companies of Saudi Arabia.

$\mathrm{H}_{02}$ : There is no relationship between revenue and operational profitability, investment, and return of energy sector companies of Saudi Arabia.

\section{Research Methodology}

The study is purely based on the secondary data taken from the websites of the energy sector companies of Saudi Arabia for the period 2012 to 2019. Aldarees, Saudi electricity co. (SECO.), Petro rabigh, and the national Shipping Corporation of Saudi Arabia (BAHRI) companies are considered for the study. The profitability of the companies is measured by calculating the ratios (Ali \& Haque, 2014). The profitability measurement bifurcated into two categories:

A. Profitability based on operational activities (revenue)

I. Gross Profit Ratio $(\mathrm{GPR})=\frac{\text { Gross Profit } * 100}{\text { Net sales or revenue }} ; \quad$ and

II. Net Profit Ratio (NPR) $=\frac{\text { Net Prof it } * 100}{\text { Net sales or revenue }}$

B. Profitability based on investments (equity and total assets)

I. Return on Equity $(\mathrm{ROE})=\frac{\text { Net Income } * 100}{\text { Equity }}$; and

II. Return on Assets $(\mathrm{ROA})=\frac{\text { Net Income } * 100}{\text { Total Assets }}$

ANOVA (Analysis of Variance) is applied to know the significance in similarity of profitability of energy companies of Saudi Arabia (Ali, A., 2020a).

$\mathrm{F}=\frac{B s s / d f 1}{W s s / d f 2} ;$ While, $\mathrm{F} \geq \mathrm{F} \propto$, Reject $\mathrm{H}_{0}$;

The ranks correlation between ranks of an average of the absolute values (revenue, equity, total assets) and relative values (GPR, NPR, ROE, and ROA) calculated to get the governance of profitability by the level of activities (revenue) and investments (equity, total assets) (Ali, A., 2020c). Spearman's Rank Correlation is applied to get the relational correlation between the ranks of absolute measurements (revenue, and equity, total assets) and relative measurements (gross profitability, net profitability, and return on equity and return on total assets) (Ali, A., 2020b).

Spearman's Rank correlation $=1-\frac{6 \sum(D * D)}{n(n * n-1)}$

\section{Analysis}

\subsection{Similarity in operational profitability and return on investment}

Normally, it is expected that there is a similarity in the profitability of the companies from the same sector until it is not influenced by any internal or external factor. To explain the difference between operational profitability and return on investment, the H01 can be divided into four subcategories:

\begin{tabular}{lllll}
\hline $\mathrm{H}$. No. & Hypotheses & $\mathrm{F}^{*}$ & $\mathrm{~F} \alpha^{* *}$ & Decision: $\mathrm{H}_{0}\left(\right.$ If $\left.\mathrm{F} \geq \mathrm{F} \alpha, \mathrm{Reject} \mathrm{H}_{0}\right)$ \\
\hline $\mathrm{H}_{0} 1.1$ & $\begin{array}{l}\text { There is no significant difference among the gross profitability of energy } \\
\text { sector companies of Saudi Arabia }\end{array}$ & 66.17 & 2.94 & Reject $\mathrm{H}_{0}$ \\
$\mathrm{H}_{0} 1.2$ & $\begin{array}{l}\text { There is no significant difference among the net profitability of energy } \\
\text { sector companies of Saudi Arabia }\end{array}$ & 26.01 & 2.94 & Reject $\mathrm{H}_{0}$ \\
$\mathrm{H}_{0} 1.3$ & $\begin{array}{l}\text { There is no significant difference among the return on owners' equity of } \\
\text { energy sector companies of Saudi Arabia }\end{array}$ & 10.37 & 2.94 & Reject $\mathrm{H}_{0}$ \\
$\mathrm{H}_{0} 1.4$ & $\begin{array}{l}\text { There is no significant difference among the return on total resources of } \\
\text { energy sector companies of Saudi Arabia }\end{array}$ & 15.27 & 2.94 & Reject $\mathrm{H}_{0}$ \\
\hline
\end{tabular}

Source: ${ }^{*} \mathrm{~F}$ values (ANOVA) calculated based on the gross profit ratio, net profit ratios, return on equity ratio, and return on total assets ratio (as given in table $1,2,3$, and 4$)$ and $* * \mathrm{~F}$ taken from the $\mathrm{F}$-table at $5 \%$ level of significance.

The above ANOVA study of the profitability measures reveals that there are significant differences in the profitability of the energy sector companies of Saudi Arabia. This indicates the difference in sales price, cost of the sales which may be due to the variation of demand of the company to company or availability of the factors of production from different sources or at different costs. 


\subsection{Relational analysis of revenue and operational profitability, and investment and return on investment}

The relationship between revenue and operational profitability, and investment and return on investment of energy sector companies of Saudi Arabia can be analyzed into four categories:

\subsubsection{Relational analysis of the revenue and gross profitability}

The relational analysis of revenue and gross profitability explains the relational order and their relationship based on the ranks of the revenue and gross profitability of the business organization and reveals the movement of the gross profitability as per the revenue.

Table 1

Relational relationship between revenue and gross profitability of energy sector companies of Saudi Arabia (Amount in thousand SR)

\begin{tabular}{|c|c|c|c|c|c|c|c|c|}
\hline \multirow[t]{2}{*}{ Years } & \multicolumn{2}{|l|}{ Aldarees } & \multicolumn{2}{|l|}{ SECO } & \multicolumn{2}{|c|}{ Petro Rabigh } & \multicolumn{2}{|l|}{ BAHRI } \\
\hline & Revenue & GPR & Revenue & GPR & Revenue & GPR & Revenue & GPR \\
\hline 2012 & 1873574 & 9.15 & 33646259 & 10.72 & 62010877 & 2.47 & 2464628 & 23.31 \\
\hline 2013 & 1982683 & 9.46 & 35672129 & 7.40 & 50597710 & 0.91 & 598660 & 16.91 \\
\hline 2014 & 2144322 & 10.59 & 38490670 & 5.27 & 54236752 & 3.18 & 771006 & 25.16 \\
\hline 2015 & 2302992 & 10.94 & 41538732 & 6.22 & 25513860 & 1.16 & 7464018 & 29.43 \\
\hline 2016 & 3461349 & 5.99 & 49914757 & 6.02 & 25146130 & 4.40 & 6788484 & 27.88 \\
\hline 2017 & 3409598 & 5.36 & 50684906 & 13.20 & 34211010 & 7.88 & 6045835 & 21.84 \\
\hline 2018 & 5176585 & 4.89 & 64063638 & 9.24 & 40998191 & 5.65 & 6129910 & 20.34 \\
\hline 2019 & 5681129 & 8.13 & 65040000 & 9.42 & 34031975 & 5.05 & 6567015 & 21.73 \\
\hline Av. & 3254029 & 8.06 & 47381386 & 8.44 & 40843313 & 3.84 & 4603695 & 23.33 \\
\hline $\mathrm{R} 1$ & 4 & & 1 & & 2 & & 3 & \\
\hline $\mathrm{R} 2$ & 3 & & 2 & & 4 & & 1 & \\
\hline $\mathrm{D}$ & 1 & & -1 & & -2 & & 2 & \\
\hline $\mathrm{D}^{2}$ & 1 & & 1 & & 4 & & 4 & $\sum \mathrm{D}^{2}=10$ \\
\hline
\end{tabular}

Source: Authors' own calculations based on the values given in the Income statement of the concerned companies available on the websites of the energy companies of Saudi Arabia.

Note: Ranks (R1 and R2) are based on the average values of revenues and gross profitability ratio.

$\mathrm{r}_{\mathrm{s}, \text { revenue. GPR }}=1-\frac{6 \sum(D * D)}{n(n * n-1)} ; \quad 1-\frac{6 \sum(10)}{4(4 * 4-1)} ; \quad 1-\frac{60}{60} ; \quad=+1$

The relational analysis of Table 1 explains that the revenue and gross profitability of energy sector companies are positively and perfectly correlated. This implies that the energy sector companies enjoy the benefit of production on a larger scale. The fixed cost in the manufacturing of energy in Saudi energy sector companies remains constant

\subsubsection{Relational analysis of the revenue and net profitability}

The relational analysis of revenue and net profitability explains the relational order and their relationship based on the ranks of the revenue and net profitability of the business organization and reveals the movement of the net profitability as per the revenue.

Table 2

Relation relationship between revenue and net profitability of energy sector companies of Saudi Arabia (Amount in thousand SR)

\begin{tabular}{|c|c|c|c|c|c|c|c|c|}
\hline \multirow[t]{2}{*}{ Years } & \multicolumn{2}{|l|}{ Aldarees } & \multicolumn{2}{|l|}{ SECO } & \multicolumn{2}{|l|}{ Petro Rabigh } & \multicolumn{2}{|l|}{ BAHRI } \\
\hline & Revenue & NPR & Revenue & NPR & Revenue & NPR & Revenue & NPR \\
\hline 2012 & 1873574 & 5.10 & 33646259 & 7.61 & 62010877 & 0.79 & 2464628 & 20.45 \\
\hline 2013 & 1982683 & 5.13 & 35672129 & 8.51 & 50597710 & 0.71 & 598660 & 23.07 \\
\hline 2014 & 2144322 & 5.77 & 38490670 & 9.37 & 54236752 & 1.26 & 771006 & 25.31 \\
\hline 2015 & 2302992 & 6.25 & 41538732 & 3.72 & 25513860 & -2.97 & 7464018 & 24.35 \\
\hline 2016 & 3461349 & 2.63 & 49914757 & 4.22 & 25146130 & 0.14 & 6788484 & 25.77 \\
\hline 2017 & 3409598 & 1.90 & 50684906 & 13.63 & 34211010 & 4.16 & 6045835 & 13.34 \\
\hline 2018 & 5176585 & 1.29 & 64063638 & 2.74 & 40998191 & 1.63 & 6129910 & 7.97 \\
\hline 2019 & 5681129 & 5.14 & 65040000 & 2.13 & 34031975 & -1.60 & 6567015 & 9.80 \\
\hline Av. & 3254029 & 4.15 & 47381386 & 6.49 & 40843313.13 & 0.51 & 4603694.5 & 18.76 \\
\hline R1 & 4 & & 1 & & 2 & & 3 & \\
\hline R2 & 3 & & 2 & & 4 & & 1 & \\
\hline $\mathrm{D}$ & 1 & & -1 & & -2 & & 2 & \\
\hline $\mathrm{D}^{2}$ & 1 & & 1 & & 4 & & 4 & $\sum \mathrm{D}^{2}=10$ \\
\hline
\end{tabular}

Source: Authors' own calculations based on the values given in the Income statement of the concerned companies available on the websites of the energy companies of Saudi Arabia.

Note: Ranks (R1 and R2) are based on the average values of revenues and net profitability ratio.

$\mathrm{r}_{\mathrm{S}, \text { revenue.NPR }}=1-\frac{6 \sum(D * D)}{n(n * n-1)} ; \quad 1-\frac{6 \sum(10)}{4(4 * 4-1)} ; \quad 1-\frac{60}{60} ; \quad=+1$ 
The relational analysis of Table 2 explains that the revenue and net profitability of energy sector companies are positively and perfectly correlated. This implies that the energy sector companies enjoy the benefit of production on a larger scale. The administrative expenses of the energy sector companies remain constant at all levels of production.

\subsubsection{Relational analysis of the Equity and return on equity}

The relational analysis of equity and net return on equity explain the relational order and their relationship based on the ranks of the equity and net return on equity of business organization and reveals the movement of the net return on equity as per the equity.

Table 3

Relational relationship between equity and return on equity of energy sector companies of Saudi Arabia (Amount in thousand SR)

\begin{tabular}{|c|c|c|c|c|c|c|c|c|}
\hline \multirow[b]{2}{*}{ Years } & \multicolumn{2}{|l|}{ Aldarees } & \multicolumn{2}{|l|}{ SECO } & \multicolumn{2}{|l|}{ Petro Rabigh } & BAHRI & \\
\hline & Equity & $\mathrm{ROE}$ & Equity & $\mathrm{ROE}$ & Equity & $\mathrm{ROE}$ & Equity & $\mathrm{ROE}$ \\
\hline 2012 & 477943 & 19.99 & 53449454 & 4.79 & $8,560,942$ & 5.71 & $5,410,914$ & 9.31 \\
\hline 2013 & 518036 & 19.63 & 56276313 & 5.39 & $8,917,457$ & 4.03 & $5,845,729$ & 2.36 \\
\hline 2014 & 580360 & 21.32 & 59242496 & 6.09 & $9,555,863$ & 7.13 & $5,725,874$ & 3.41 \\
\hline 2015 & 642994 & 22.40 & 60349127 & 2.56 & $8,351,398$ & -9.08 & $9,284,658$ & 19.58 \\
\hline 2016 & 633725 & 14.36 & 62023623 & 3.39 & $8,395,516$ & 0.41 & $9,677,928$ & 18.08 \\
\hline 2017 & 655764 & 9.86 & 72309407 & 9.55 & $10,085,807$ & 14.11 & 9495218 & 8.49 \\
\hline 2018 & 643256 & 10.40 & 73677778 & 2.38 & 10542020 & 6.34 & 9377871 & 5.21 \\
\hline 2019 & 874767 & 33.35 & 73569872 & 1.89 & 10041407 & -5.42 & 9212167 & 6.99 \\
\hline Av. & 628356 & 18.91 & 63862259 & 4.51 & $9,306,301$ & 2.90 & $8,003,795$ & 9.18 \\
\hline $\mathrm{R} 1$ & 4 & & 1 & & 2 & & 3 & \\
\hline $\mathrm{R} 2$ & 1 & & 3 & & 4 & & 2 & \\
\hline $\mathrm{D}$ & 3 & & -2 & & -2 & & 1 & \\
\hline $\mathrm{D}^{2}$ & 9 & & 4 & & 4 & & 1 & $\sum \mathrm{D}^{2}=18$ \\
\hline
\end{tabular}

Source: Authors' own calculations based on the values given in the Income statement and Balance sheet of the concerned companies available on the websites of the energy companies of Saudi Arabia.

Note: Ranks (R1 and R2) are based on the average values of revenues and net profitability ratio.

$\mathrm{r}_{\mathrm{s}, \text { Equity.return on Equity }}=1-\frac{6 \sum(D * D)}{n(n * n-1)} ; \quad 1-\frac{6 \sum(18)}{4(4 * 4-1)} ; \quad 1-\frac{108}{60} ; \quad=-0.8$

The relational analysis of Table 3 explains that equity and return on equity of energy sector companies are negatively and highly correlated. This implies that there is an underutilization of the resources or overcapitalization in energy sector companies of Saudi Arabia. Further, the issuance of equity capital is not favorable for the profitability and owners of energy sector companies of Saudi Arabia.

\subsubsection{Relational analysis of the total assets and return on total assets}

The relational analysis of total assets and net return on assets explains the relational order and their relationship based on the ranks of the total assets and net return on assets of business organization and reveals the movement of the return on total assets as per the total assets.

Table 4

Relational relationship between total assets and return on equity of energy sector companies of Saudi Arabia (Amount in thousand SR)

\begin{tabular}{|c|c|c|c|c|c|c|c|c|c|}
\hline \multirow{2}{*}{ Years } & \multicolumn{2}{|l|}{ Aldarees } & \multicolumn{2}{|l|}{ SECO } & \multicolumn{2}{|l|}{ Petro Rabigh } & \multirow{2}{*}{$\begin{array}{l}\text { BAHRI } \\
\text { TA }\end{array}$} & \multirow[b]{2}{*}{ ROA } & \\
\hline & TA & ROA & $\mathrm{TA}$ & ROA & TA & ROA & & & \\
\hline 2012 & 927708 & 10.30 & $238,798,378$ & 1.07 & $47,775,549$ & 1.02 & $11,063,609$ & 4.56 & \\
\hline 2013 & 1089107 & 9.34 & $276,787,644$ & 1.10 & $45,593,819$ & 0.79 & $11,996,528$ & 1.15 & \\
\hline 2015 & 1258920 & 11.44 & $358,029,949$ & 0.43 & $51,341,049$ & -1.48 & $19,096,651$ & 9.52 & \\
\hline 2016 & 1541246 & 5.91 & $402,970,775$ & 0.52 & $58,246,047$ & 0.06 & $20,837,255$ & 8.40 & \\
\hline 2017 & 1790167 & 3.61 & $445,760,460$ & 1.55 & $61,674,977$ & 2.31 & 21182583 & 3.81 & \\
\hline 2019 & 3585220 & 8.14 & 464555844 & 0.30 & 74029648 & -0.74 & 20560827 & 3.13 & \\
\hline Av. & 1853647 & 7.62 & 371170886 & 0.81 & $55,461,356$ & 0.58 & $17,279,633$ & 4.31 & \\
\hline $\mathrm{R} 1$ & 4 & & 1 & & 2 & & 3 & & \\
\hline $\mathrm{R} 2$ & 1 & & 3 & & 4 & & 2 & & \\
\hline $\mathrm{D}$ & 3 & & -2 & & -2 & & 1 & & \\
\hline $\mathrm{D} 2$ & 9 & & 4 & & 4 & & 1 & & $\sum \mathrm{D} 2=18$ \\
\hline
\end{tabular}

Source: Authors' own calculations based on the values given in the Income statement and Balance sheet of the concerned companies available on the websites of the energy companies of Saudi Arabia.

Note: Ranks (R1 and R2) are based on the average values of revenues and net profitability ratio. 
$\mathrm{r}_{\mathrm{s}, \mathrm{TA} . \mathrm{ROA}}=1-\frac{6 \sum(D * D)}{n(n * n-1)} ; \quad 1-\frac{6 \sum(18)}{4(4 * 4-1)} ; \quad 1-\frac{108}{60} ; \quad=-0.8$

Relational analysis of Table 4 explains that total assets and return on total assets of energy sector companies are negatively and highly correlated. This implies that there is an underutilization of the total resources or overcapitalization in energy sector companies of Saudi Arabia. Further, making investments in resources of energy sector companies is not beneficial for return or profitability's point of view.

\section{Discussion}

The results of the study of profitability differences based on the profitability reveal that there are significant differences among the profitability of the energy sector companies. The gross profitability and net profitability of the energy sector companies are different. Also, the return on owners' funds and total resources is different, relatively. Samargandi et al. (2014) also explained that the financial performance of the petrochemical companies governed by some internal external factors. Possibly, external factors i.e. the demand of the energy products and prices, and internal factors i.e. manufacturing and administrative expenses or inefficiency responsible for the low operational performance or reasons for significant differences in the profitability of the Saudi Arabian energy companies. Kumar et al. (2016) and Ben-Caleb et al. (2013) explored that the management of current assets and current liabilities affects profitability. The high level of activities also affects the profits and profitability positively due to the constant behavior of the period costs. Khan et al. (2014) advocated the operational velocity or production level to enhance profitability. The relational relationship between the revenue and gross profitability, and revenue and net profitability of energy sector companies are positively and perfectly correlated. This implies that the energy sector companies enjoy the benefit of production on a larger scale. The administrative expenses of the energy sector companies remain constant at all levels of production. The relational relationship of return on equity and return on total assets reveals the high negativity in energy sector companies of Saudi Arabia. This implies that there is underutilization of the total resources or overcapitalization in energy sector companies of Saudi Arabia. Lele (2016) also found the negativity of return on owners' funds in the non-financial companies registered in Saudi Arabia.

\section{Conclusion}

Based on above all analysis and discussion it can be concluded that gross profitability and net profitability and return on funds or return on total resources of the energy sector companies of Saudi Arabia is significantly different. The primary reasons for the difference in profitability are internal while the external factors do not affect the profitability similarly to all business organizations. Internal factors and demand of the product that governs the level of production and makes the difference in the profitability of the smaller and bigger companies. There is a need to control the manufacturing and administrative expenses or managerial inefficiency of the energy sector companies of Saudi Arabia. The relational relationship between the revenue and equity, and revenue and total assets is highly and negatively correlated. This indicates the overcapitalization or underutilization of resources in energy sector companies in Saudi Arabia and suggests no further investment by issuing the equity capital or raising the loans. Finally, the energy sector companies needed to enhance their revenue by increasing the level of production activities without any further investments in operational activities. The enhancing of the level of production activities is only possible due to the enhancement of velocity of the operational activities by managerial efficiency and optimum utilization of the resources, provided that the enhancement of operational level of production by the extended investment is not favorable in energy sector companies in Saudi Arabia. The study is based on the secondary data of only four years of leading energy companies of Saudi Arabia. The size determinants can also be considered as a variable for the relative profitability study of the energy sector companies of Saudi Arabia.

\section{Acknowledgement}

The author would like to thank the Deanship of Scientific Research, Prince Sattam Bin Abdulaziz University, Saudi Arabia.. 


\section{References}

Akhtar, M. H., \& Asif, M. (2017). Evaluating managerial efficiency of petrochemical firms in Saudi Arabia. Benchmarking: An International Journal, 24(1), 244-256. https://doi.org/10.1108/BIJ-06-2014-005

Alagathurai, A. (2013). A nexus between liquidity \& profitability: a study of trading companies in Sri Lanka. Ajanthan, A.(2013). A Nexus Between Liquidity \& Profitability: A Study Of Trading Companies In Sri Lanka. European Journal of Business and Management, 5(7), 221-237.

Ali, A. (2020a). Financial performance and size determinants: growth trend and similarity analysis of Indian pharmaceutical industry. Humanities \& Social Sciences Reviews, 8(4), 547-560.

Ali, A. (2020b). Firm size and solvency in Indian pharmaceutical sector: A relational co-movement analysis. Accounting, 6(7), 1199-1208.

Ali, A. (2020c). Working capital, profit and profitability: An absolute and relational study of selected leading Indian pharmaceutical firms. Accounting, 6(6), 951-960.

Ali, A. (2020d). Volatility of Oil Prices and Public Spending in Saudi Arabia: Sensitivity and Trend Analysis. International Journal of Energy Economics and Policy, 11(1), 165-172.

Ali, A., \& AbuTheeb, E. (2018). Financial Performance of Petrochemicals Industry in Saudi Arabia: Pre and Post Global Economic Recession. International Journal of Management studies, 4(8), 21-29. https://doi.org/10.18843/ijms/v5i4(8)/03

Ali, A., \& Haque, M. I. (2014). Ratio Analysis: A Comparative Study of National Petrochemicals Co. and Sahara Petrochemicals Co. of Saudi Arabia. International Journal of Management Academy, 2(4), 53-61.

Al-Shuaibi, K., Zain, M., \& Kassim, N. (2016). Performance indicators for quality, innovation, and competitiveness: A survey on the Saudi manufacturing sector. International Business Research, 9(2), 99-113. https://doi.org/10.5539/ibr.v9n2p99

Aminu, Y. (2012). A nexus between liquidity/profitability trade-offs for working capital management in Nigerias manufacturing sector. International Journal of Arts and Commerce, 1(6), 55-58.

Ben-Caleb, E., Olubukunola, U., \& Uwuigbe, U. (2013). Liquidity management and profitability of manufacturing companies in Nigeria. IOSR Journal of Business and Management, 9(1), 13-21.

Bhunia, A., Khan, I., \& MuKhuti, S. (2011). A study of managing liquidity. Journal of Management Research, 3(2), 1-22.

Ehiedu, V. C. (2014). The impact of liquidity on profitability of some selected companies: The financial statement analysis (FSA) approach. Research Journal of Finance and Accounting, 5(5), 81-90.

Farhan, N. H., Alhomidi, E., Almaqtari, F. A., \& Tabash, M. I. (2019). Does Corporate Governance Moderate the Relationship between Liquidity Ratios and Financial Performance? Evidence from Indian Pharmaceutical Companies. Academic Journal of Interdisciplinary Studies, 8(3), 144-144.https://doi.org/10.5539/ijbm.v11n8p203

Khan, M. Z. R. M. N., \& Khokhar, I. (2014). Select financial ratios as a determinant of profitability evidence from petrochemical industry in Saudi Arabia. European Journal of Business and Management, 6(6), 187-196.

Kumar, S., Srivastava, P., Sinha, S. K., \& Goyal, R. (2016). A Study of Financial Efficiency and Liquidity Position of Indian Pharmaceutical Industry Special Reference to Cipla Ltd. International Journal of Innovations in Engineering and Technology, $7(1), 702-711$.

Lele, U. (2016). Impact of oil prices on revenue growth and profitability of Saudi listed companies in non-financial sectors. International Journal of Management, Information Technology and Engineering, 4(6), 13-20.

Panigrahi, C. M. A. (2019). Liquidity and Profitability Relationship and Financial Fallacy. Think India Journal, 22(10). 704-718.

Panigrahi, C. M. A., Raul, N., \& Gijare, C. (2018). Liquidity and profitability trade-off: A study of Indian pharmaceutical companies. NMIMS Journal of Economics and Public Policy, 3(1), 42-56.

Priya, K., \& Nimalathasan, B. (2013). Liquidity management and profitability: A case study of listed manufacturing companies in Sri Lanka. International Journal of Technological Exploration and Learning, 2(4), 161-165.

Pushparaj Kulkarni, D., \& Pimplapure, V. (2019). An Analytical Study of Profitability of Pharmaceutical Companies in India. Journal of the Gujarat Research Society, 21(16), 50-57.

Rehman, M.Z., Khan, N.M., \& Khokhar, I. (2015). Investigating Liquidity-Profitability Relationship: Evidence from Companies Listed in Saudi Stock Exchange (Tadawul). Journal of Applied Finance \& Banking, 5(3), 159-173.

Samargandi, N., Fidrmuc, J., \& Ghosh, S. (2014). Financial development and economic growth in an oil-rich economy: The case of Saudi Arabia. Economic Modelling, 43, 267-278. http://dx.doi.org/10.1016/j.econmod.2014.07.042

Sinha, S. K., Goyal, R., Kumar, S., \& Gupta, V. A (2016). Study on Engineering of Cash Management and its impact on Profitability of Indian Pharmaceutical Industry with Special Reference to Cipla Ltd. International Journal of Innovations in Engineering and Technology (IJIET),6(4), 469-478.

Sodha, S. (2020). A Comparison of Pharma Companies Based on Profitability and Liquidity. Tathapi with ISSN 2320-0693 is an UGC CARE Journal, 19(24), 157-162. 


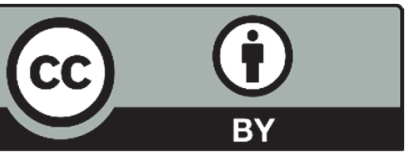

(C) 2021 by the authors; licensee Growing Science, Canada. This is an open access article distributed under the terms and conditions of the Creative Commons Attribution (CC-BY) license (http://creativecommons.org/licenses/by/4.0/). 